\title{
The discretionary use of oil revenues in Brazil: Federal dynamics
}

\author{
BENI TROJBICZ ${ }^{1}$ \\ CATARINA IANNI SEgATTO ${ }^{2}$

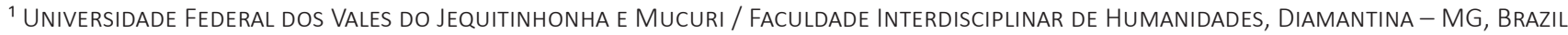 \\ 2 Universidade Federal do ABC / Centro de Engenharia, Modelagem e Ciências Sociais Aplicadas, SÃo Bernardo do CAMpo - SP, Brazil
}

\begin{abstract}
This article analyzes the Brazilian case of federal centralization of oil revenues, to show how jurisdictions' preferences may direct federal dynamics through central federative mechanisms. The study uses historical and institutional approaches that explain continuity and change in territorial regimes. Specifically, we analyse the loss of discretionary power in the use of oil resources through the understanding whether and how these changes affected the approval of National Law 12858 in 2013, which determined that federal government, states, and municipalities should spend their share of oil revenues on education and health. We show the way subnational preferences affect federal policies, highlighting the importance of causality and context, both politically and institutionally, and indicating a return to a governability pattern that seemed to be buried with the economic stabilization plan of 1994.
\end{abstract}

Keywords: Federalism. Oil revenues. Brazil.

\section{Uso discricionário das receitas de petróleo no Brasil: dinâmicasfederativas}

\section{Resumo}

Este artigo analisa o caso brasileiro de centralização federal das receitas do petróleo, para mostrar como as preferências das jurisdições podem direcionar a dinâmica federal por meio de mecanismos federativos do centro. O estudo trabalha abordagens históricas e institucionais que explicam continuidade e mudança nos regimes territoriais. Especificamente, analisamos a perda de poder discricionário no uso de recursos petrolíferos por meio da avaliação de se e como essas mudanças afetaram a aprovação da Lei Nacional 12.858 em 2013 , que determinou que o governo federal, estados e municípios devem gastar sua parcela das receitas do petróleo em educação e saúde. Mostramos a forma como as preferências subnacionais afetam as políticas federais, destacando a importância da causalidade e do contexto, institucional e político, indicando um retorno a um padrão de governabilidade que parecia estar enterrado com o plano de estabilização econômica em 1994.

Palavras-chave: Federalismo. Receitas petrolíferas. Brasil.

\section{Uso discrecional de los ingresos petroleros en Brasil: dinámica federativa}

\section{Resumen}

Este artículo analiza el caso brasileño de centralización federal de los ingresos petroleros, para mostrar cómo las preferencias de las jurisdicciones pueden dirigir la dinámica federal a través de mecanismos federativos del centro. El estudio trabaja enfoques históricos e institucionales que explican la continuidad y el cambio en los regímenes territoriales. Específicamente, analizamos la pérdida de poder discrecional en el uso de los recursos petroleros evaluando si estos cambios afectaron a la aprobación de la Ley Nacional 12.858 en 2013, que determinó que el gobierno federal, los estados y los municipios deberían gastar su parte de los ingresos petroleros en educación y salud. Mostramos cómo las preferencias subnacionales afectan a las políticas federales, destacando la importancia de la causalidad y del contexto, institucional y político, indicando un regreso a un patrón de gobernabilidad que parecía estar enterrado con el plan de estabilización económica en 1994.

Palabras clave: Federalismo. Ingresos petroleros. Brasil. 


\section{INTRODUCTION}

In 2013, Brazilian federal executive and legislative approved Law 12,858 at the national level, determining that federal government, states, and municipalities should spend their share of oil revenues on education and health. Although the law signals a loss in the discretion to allocate these resources for all government levels, a close scrutiny of the process unveils a federal dynamic that benefits subnational units over the Union, as they will enjoy discretion over oil revenues for a longer time.

The literature shows that, overall, there has been a process of federal re-centralization in Brazil since the 1990s (ARRETCHE, 2003, 2012). The 1988 Constitution determined shared competencies in most policies, and the federal government had been increasing its participation in decision-making through national regulation and intergovernmental transfers. As a result, the Union has greater decision powers over jurisdictions, being at the center in national decisions in most policies, while jurisdictions have attributions of policy-making (ARRETCHE, 2012). Moreover, the scholarly literature on the executive-legislative relations shows that, at the national level, the executive has important legislative and agenda powers, allowing it to approve bills and hold legal dominance. Within the National Congress, parliamentarians delegate power to party leaderships, creating party cohesion and consistent coalitions (FIGUEIREDO and LIMONGI, 2007).

In the light of those specificities, this study seeks to comprehend the patterns in executive-legislative decision-making process, in particular, in the approval of the Law no. 12.858 in 2013, including if and how states and municipalities influenced this decision, as well as other conditioning factors. The study of changes in oil revenue allocation in Brazil is particularly interesting to this debate, as it points to different empirical objects and, therefore, allows for an alternative scenario that probes established theories in several ways. The first is that its object is not frequent in Brazilian Public Policy studies, as it deals with Oil sector policies, which allows probing how different sets of institutions and sectoral actors affect federal dynamics. The second is that it deals with a specific type of centralization, the loss of discretionary subnational power in the use of oil resources. The third is that this centralization was approved within a context of allocation of oil revenues that benefits producing regions, states and municipalities, exposing a dynamic that opposes producing and non-producing jurisdictions (BRASIL, 2010, 2012, 2013). Fourth, this decision took place when the president's popular support was low, a rupture in a pattern that had prevailed since 1994. As well, the approach is innovative as it focuses on interactive processes and how they impact policy-making.

The policy evolution in the oil arena led to a federal dispute for oil rents between producing and non-producing jurisdictions. This issue erupted in 2009, when the federal government proposed a new model for deep water oil exploration that left the concentration of oil revenues in producing states and municipalities unaltered. After a long legislative battle for a more equitable division, which included two presidential vetoes and a veto overthrow, producing states took the issue to the Supreme Court in March 2013.

Methodologically, this case study allows the understanding of if and how timing and sequence can be a causal mechanism in a federative context affecting changes. Therefore, it uses secondary data from legislative debates between 2009 and 2013 in the House of Representatives and the Senate, legislation, governmental reports, previous publications, and media coverage. As well, primary data was provided by in-depth interviews between 2014 and 2015 with members of Congress, specialists, and key informants. Interviewees are listed in Annex 1; suppressed names indicate requests for anonymity. Finally, data from different sources was cross-referenced to add reliability. Our analysis is based in the discussion of historical and institutional dynamics of federal systems, as oil revenues consist of a sizeable source of income that recognizably generates regional conflicts. The analyses relies on the discussion of federalism through a historical and qualitative approach, which is grounded on the literature on federal dynamics that discusses the mechanisms of continuity and change in territorial regimes and other historical and institutional approaches, in particular causation in time, sequencing, and multilayers of context in policy analysis (BENZ and BROSCHEK, 2013; BROSCHEK, PETERSOHN and TOUBEAU, 2018). 


\section{DECISION-MAKING, FEDERAL DYNAMICS, AND GOVERNABILITY}

The scholarly literature on Brazilian federalism shows that the country combines centralized and decentralized features. Most policies, including the oil policy, had a centralized legacy. Arretche (2012) shows steady centralization since the 1930s, which has concentrated the policy formulation in the center while delegating policy implementation to jurisdictions. Nevertheless, the 1988 Constitution changed this path, decentralizing most policies. As a result, states and municipalities increased their political, administrative, and fiscal autonomy in policymaking, especially in social policies, even though the new Constitution established shared responsibilities with the federal government in most policy fields.

In the oil sector, centralization is the norm, and the federal government has had ownership of the oil, and responsibility for oil extraction, production, transportation, and commercialization through state-owned national company Petrobras. The new Constitution gave Petrobras the monopoly of the national oil exploration, and left the federal oil ownership unchanged, therefore it retained the federal government as the main decision-maker. However, it transferred a significant parcel of oil revenues to producing states and municipalities (BRASIL, 1988, 1989). Despite the 1990's market-oriented reforms that ended the state-company monopoly of oil exploration and distribution, Petrobras remained the main player in the oil industry (FELIPE, 2010; TROJBICZ, 2016).

Since the mid-1990s, the federal government increased its role in policymaking in different policies, particularly education, health, and social assistance through the approval of national standards and regulations, the adoption of project-grants, and the creation of an equalization system for education (ARRETCHE, 2012; FENWICK, 2009; SEGATTO and ABRUCIO, 2018). Some changes had also implications in subnational spending, decreasing subnational discretion, such as the Law of Fiscal Responsibility (Lei de Responsabilidade Fiscal). This also affected social policies. In education, the Fund for Maintenance and Development of Primary Education and Valorization of Teaching (Fundo de Manutenção e Desenvolvimento da Educação Fundamental e de Valorização do Magistério - FUNDEF) and later the Fund for Maintenance and Development of Education and Valorization of Education Professionals (Fundo de Manutenção e Desenvolvimento da Educação Básica e de Valorização dos Profissionais da Educação - FUNDEB) redistributed revenues among states and municipalities according to students' enrollments, as well as determined a minimum spending for educational profession (BRASIL, 1996, 2006). In health care, national legislation determined minimum spending in health care for states and municipalities (Constitutional Amendment $n^{\circ}{ }^{29}$ ) and created project grants for primary health care (Norma Operacional Básica, NOB/96) (BRASIL, 1996, 2000). More recently, the approval of the Law 12,858 followed this path towards more centralization, i.e., decreasing subnational discretionary in spending.

The scholarly literature states that these policy changes are related to intergovernmental relations in Brazil, leading to a model that combines centralized features (federal government's policy decision-making powers) with decentralized features, as jurisdictions have powers of policy-making. The prominence of the federal government decreases inequalities among jurisdictions and ensures common standards across the country (ARRETCHE, 2012). Other scholars agree that different policies were characterized by an increase in federal government's role as a coordinator, but subnational autonomy remains and influences policymaking (BICHIR, SIMONI JUNIOR and PEREIRA, 2020).

Some scholars propose a different approach to study federalism and public policies. They argue that institutional arrangements and federal dynamics are a result of policy ideas, policy legacies, and how they shape actors' preferences and choices, and politics, including political coalitions and, in this case, the articulation of subnational territorial entities' interests at the center (BENZ and BROSCHEK, 2013; BROSCHEK, PETERSOHN and TOUBEAU, 2018). ${ }^{1}$ Changes are influenced by exogenous and endogenous factors. In the case of exogeneous factors, moments of critical junctures, influenced by external shocks, change the political context and hegemonic ideas. In the case of endogenous factors, the intersection between institutions, actors and ideas "do not necessarily evolve in unison or conformity with one another. As a result, 'frictions' may emerge, i.e., tensions between the principles and practices that structure each layer" (BROSCHEK, PETERSOHN and TOUBEAU, 2018, p. 12).

Explaining the factors that influenced the changes to the oil revenue allocation in Brazil, in particular the approval of Law 12,858 in 2013 also requires the discussion on decision making at the national level and, consequently, the governability.

\footnotetext{
${ }^{1}$ Pierson (2004) highlights the importance of policy legacy, but points out that time and sequence matter as previous decisions work as a self-reinforcing factor influencing political actors' interests and decisions.
} 
This is the case as the scholarly literature points out to the necessity of understanding executive-legislative relations to better grasp national decision making.

Analyses of Brazil's political system assess governability through the intersection of the effects of three institutional features: presidentialism, federalism, and multiparty system. Some scholars show that the combination of a fragmented party system and federalism leads to problems of governability due to scattered decision power. Other scholars state that these institutional characteristics lead to a paralysis in policymaking due to conflicts between Executive and Legislative at the national level. The Presidency reacts to Legislative using its decision power, excluding other political actors. This dynamic not only affects democracy and representation but also results in revenge from the excluded actors, producing ungovernability. These two perspectives were challenged by the political dynamics that emerged during Fernando Henrique Cardoso's government. In the context of economic stabilization, the president used intensively proactive instruments, resulting in a positive outcome in governability. Figueiredo and Limongi (2007) is an example of the latter group of scholars (PALERMO, 2000).

However, it is important to notice that these approaches rely on Brazil's institutional features to explain governability outcomes, emphasizing structure in detriment of agency. Critics point to the excessive reliance on formal rules at the expense of the political process analysis, in which actors and interests have a higher prevalence. Throughout the democratic period that started in 1988, centrifugal institutions are present, while during the period of higher governability, there is a centripetal agency influence. In other words, as institutional features were constant, and decision-making patterns changed over time, this means that a historic analysis is key to understand a hidden variable that influenced governability variation (ARMIJO, LESLIE, FAUCHER et al., 2006; PALERMO, 2016).

We seek to contribute to this debate analysing the intersections among institutions and agency through a historical analysis. Was the approval of Law 12,858 in 2013 a result of a change in federal dynamics in Brazil? If so, how does it relate to governability patterns of continuity or change? And what factors, exogenous and endogenous, do explain this change? Policy legacies, ideas, and political coalitions?

\section{THE FEDERAL DISPUTE FOR OIL RENTS}

Following the military rule, when oil rents were not assigned to subnational jurisdictions, the 1988 Constitution determined the distribution of those revenues, while prioritizing producing regions. The Law 7,990/1989 regulated this arrangement, benefitting jurisdictions geographically close to the oil fields, mainly the state of Rio de Janeiro and some of its coastal cities. The defense of this arrangement often mentions the exchange of the VAT earnings of petroleum and oil derivates: in Brazil, VAT is credited to the state of origin, which in the case of oil would favor producing states. Therefore, in the Constitution, this VAT charge was reverted to states of destination, which composes an exchange of VAT revenues for oil rents (DIAS and RENAULT, 2013; FERRARI, 2013).

In the mid-1990s, President Fernando Henrique Cardoso promoted market-oriented reforms in many economic sectors. The reform of petroleum was embodied by Law 9,478 in August 6, 1997, the so-called "Oil Law." To approve the new regulation, it was necessary to approve two constitutional amendments. The first, amendment 6 , relaxed the conditions that determine a national company in Brazil, and the second, amendment 9, ended Petrobras's monopoly on hydrocarbons exploration in Brazil. These two constitutional amendments grounded the liberalization of the country's oil and gas exploration and production and thus allowed the activity of foreign oil companies in Brazil (TROJBICZ, 2016).

As a result, Petrobras no longer managed the sector. This attribute was transferred to the new regulatory agency, the National Petroleum Agency (Agência Nacional do Petróleo Gás Natural e Biocombustiveis, ANP). In addition, the state-owned company was released from the rules of public sector control in purchases and bids in order to give it more agility to compete with other companies that entered the domestic market. Finally, in 1999, the company went through organizational restructuring. The changes preceded a substantial increase in the volume of oil extracted in Brazil, which, together with the hike in international prices from the year 2000 on, resulted in a sizeable increase in the importance of the sector: its share of the Brazilian GDP 
went from $2.8 \%$ in 1997 to $10.5 \%$ in 2005 . As mentioned, this was a period of enormous expansion of the international value of oil and gas. While the volume of oil extracted doubled between 1998 and 2009, the average value of the barrel of oil was even more extraordinary: the average price of the barrel increased from US\$13.56 to US\$ 83.46, between 1998 and 2008. As a result, revenues from oil exploration companies in Brazil increased from $R \$ 15.3$ billion in 1998 to $R \$ 97.8$ billion in 2008, although decreasing to R\$ 73.8 billion in 2009 (FELIPE, 2010).

Government participations (participações governamentais) over oil rents followed this growth, and increased from $\mathrm{R} \$ 1.7$ billions in 1998 to $\mathrm{R} \$ 25.4$ billions in 2008. Of those earnings, royalties and special participations (participações especiais) are shared with states and municipalities, and correspond to about $90 \%$ of total government participations.

In 2007, Petrobras discovered enormous oil reservoirs in the pre-salt layer of the continental shelf. This constitutes an exogenous influence, and from this discovery, studies asserted the need for a new regulatory framework to explore the oil in this region based on its lower exploratory risk. The results of this study were the bills for the proposed legal framework for activities in the pre-salt polygon. According to members of Congress interviewed, parliamentarians from the non-producing jurisdictions were dissatisfied with the federative distribution of oil resources before National Congress received the project of the federal executive for the regulation of pre-salt fields - bills 5,938, 5,939, 5,940 and 5,941 - dated September 1, 2009. Therefore, during the decision-making process of these bills, an important federative dispute erupted, in which less favored jurisdictions with royalty revenues tried to impose a more equitable distribution to the subnational jurisdictions (TROJBICZ, 2019)2. This evidences the friction between the territorial and social institutional layers.

The federative dispute for the oil rents started in the Lower House, as the Ibsen Amendment (Amendment 387 to PL5,938/2009) proposed a more equitable distribution of oil rents among federative jurisdictions. The Senate then combined two of the proposed bills, modifying some aspects of the Ibsen Amendment, which was replaced by the Pedro Simon Amendment. The latter charged the union resources for the losses that the redistribution imposed to the producing jurisdictions. This material returned to the House of Deputies and was approved as Law 12,351 of December 22, 2010.

Then, President Lula vetoed the article that aimed to modify the distribution of royalties by means of message 707/10 and sent a new bill $(8,051)$ on the last day of his government, December 31, 2010. The reason pointed out by the executive for the veto is related to the Union's need for reimbursement of the losses of the confronting jurisdictions. However, according to interviewees, the power of influence of the governor of Rio de Janeiro, Sérgio Cabral, and the Rio de Janeiro members of Congress afilliated with the PMDB, the largest party of Congress, also influenced this process. ${ }^{3}$

As mentioned, the Senate merged two law projects, which allowed the Upper House to employ one of the Lower Chamber projects to restart the issue. Parliamentarians dissatisfied with the president's veto on the distribution of royalties directed Senate Bill no. 448/2011 (PLS 448/11) to the House as Bill 2,565/2011 and approved it in the form of Law 12,734 of November 30, 2012. Once again, the federal executive vetoed the distribution of resources and Congress overthrew the veto on March 6, 2013. This motivated a direct action of unconstitutionality moved by the confronting states (Rio de Janeiro, Espírito Santo and São Paulo) in the federal Supreme Court. In March, $18^{\text {th }} 2013$, one of the Supreme Court judges suspended the effect of the Law 12,734/2012, maintaining the bulk of the resources to the confronting states and municipalities. This process, just a few months before the debates over the use of oil rents, conditioned the process and the approval of Law 12,858 , underlying the importance of time and sequence.

\section{June journeys and its influence over changes in the oil revenue distribution}

In June 2013, massive street protests took place in Brazil and modified important aspects of the political system. These protests feature an external shock, that started with a mobilization in the City of São Paulo in response to the increase in the public transportation fare, but gained notoriety for police repression and destruction of assets, with a further substantial increase of participants. From then on, the movement absorbed additional claims, including a discontent with the provision of public

${ }^{2}$ Ibsen Pinheiro (PMDB-RS) and Humberto Souto (PPS-MG) were interviewed for this research in June 2014 and February 2015 respectively. They are the authors of the Ibsen amendment.

${ }^{3}$ Two of the expert legislative consultants in mines and energy, interviewed for this research, made such a statement. 
services and with the corruption of the political class (SINGER, 2013). These demonstrations attested to the popular discontent over pivotal national issues, and impacted the popularity of politicians in general, while President Dilma Rousseff's popularity suffered radically (DATAFOLHA, 2013).

The president responded to these claims with symbolic recognition, proposing five national pacts on health, education, transport, fiscal responsibility and political reform, including the combat of corruption, which required the approval of the National Congress. The president stated that $100 \%$ of oil revenues would be spent on education in order to reach or surpass the goal of $10 \%$ of the GDP investment in the area. This objective was determined by the National Plan of Education in discussion in the Federal Senate.

The changes in the distribution of oil revenues were introduced on May 2, through the national Bill no. 5,500 (PL 5,500/2013), prior to the national protests. Therefore, the existence of such a bill before the political turmoil was strategic for the president's response, working as a self-reinforcing factor that had implications in political actors' decisions. Sequence was key in this process, as the demonstrations got it into the center of the political debate. The National Congress also interrupted parliamentary vacations and started voting on proposals in response to these claims, among them the aforementioned PL 5,500/2013. ${ }^{4}$

The Brazilian system of oil rents is complex, as it entails three fiscal systems with changing combination of levies depending on the specifics of the exploration. On top of that, the federal distribution of those rents also varies. As this mishmash impacts the understanding of the changes that the political system operated in the bill, it is important to briefly outline its intricacies.

There are three fiscal systems for oil exploration in Brazil. The concession system (Royalties and Tax $-R / T$ ), created by the Law 9,738/1997 is currently applied to non-pre-salt areas. ${ }^{5}$ However, many areas that were conceded before the discovery of those oil deposits were performed with the concession model. Therefore, there are many wheels in the pre-salt area that are explored with this model. The Production Sharing Contract (PSC) system, introduced by Law 12,351/2010 is applied exclusively to the pre-salt areas. ${ }^{6}$ This system includes sharing oil production, so called profit oil, between concessionary and state. The Onerous Cession (Cessão Onerosa) is the third fiscal system operating in Brazil, created by the Law 12,276/2010, through which the union onerously transfers to Petrobras five billion oil barrels in pre-salt specified fields.

There are four types of oil levies or government participations (participações governamentais): royalties, special participations (participações especiais), subscription bonus (bônus de assinatura) and payment for occupation and retention of area (pagamento por ocupação ou retenção de área). These levies have different federal destinations, as royalties and special participations are shared with subnational entities in varying proportions depending of the exploration, while subscription bonus and payment for occupation and retention of area remains solely with the union. The concession includes all four levies. The PSC does not charge special participation, and the profit oil performs its role.

Moreover, royalties' rates and federal distribution varies according to fiscal regime, field productivity, and location. Concession systems charge from 5 to $10 \%$, while PSC charges $15 \%$, with different distributions. Concession systems also have different distributions depending on whether the exploration is offshore or onshore. Box 1 summarizes the oil exploration systems and their levies in Brazil.

\footnotetext{
${ }^{4}$ Representative Mauro Mendonça Filho (DEM-PE): in a speach on the Ordinary Deliberative Session, June 25th, 2013, p. 26356.

Representative André Figueiredo (PDT-CE) in a speech on the Ordinary Deliberative Session, June 25th, 2013, p. 26192.

Representative Mauro Benevides (PMDB-CE) in a speech on the Ordinary Deliberative Session, June 25th, 2013, p. 26123-4

Representative Leonardo Monteiro (PT-MG) in a speach on the Ordinary Deliberative Session, June 25th, 2013, p. 26141.

Representative Mário Heringer (PDT-MG) in a speech on the Ordinary Deliberative Session, July 10th, 2013, p. 29764.

Representative Iracema Portella (PP-PI) in a speech on the Ordinary Deliberative Session, July 10th, 2013, p. 29828.

${ }^{5}$ For a more detailed description of the concession and PSC systems, see Humpreys, Sachs and Stiglitz (2007).

${ }^{6}$ The Law $13.365 / 2016$ changed some aspects this as it ended the compulsory $30 \%$ participation in the consortiums that explore pre-salt fields and allowed other oil companies to be the consortium operators, which was previously restricted to Petrobras.
} 
Box 1

Oil exploration systems and their levies in Brazil

\begin{tabular}{|l|l|l|l|l|}
\hline & \multicolumn{1}{|c|}{ Royalties } & \multicolumn{1}{|c|}{ Special Participations } & \multicolumn{1}{|c|}{ Subscription Bonus } & \multicolumn{1}{|c|}{$\begin{array}{c}\text { Payment for Occupation } \\
\text { and Retention of Area }\end{array}$} \\
\hline Concession & $\begin{array}{l}\text { From } 5 \% \\
\text { to } 10 \%\end{array}$ & $\begin{array}{l}\text { Defined based on the oil } \\
\text { field productivity }\end{array}$ & $\begin{array}{l}\text { Criteria for defining } \\
\text { auction winner }\end{array}$ & Paid yearly \\
\hline Profit Sharing & $15 \%$ & Substituted by Profit oil & Fixed amount & Exempted \\
\hline Onerous Cession & $\begin{array}{l}\text { From } 5 \% \\
\text { to } 10 \%\end{array}$ & Exempted & Exempted & Exempted \\
\hline
\end{tabular}

Source: Elaborated by the authors.

Additionally, oil exploration encompasses some landmarks. The first one is the contract signature, after which the concessionary starts prospection and, if successful, it issues the declaration of commerciality. Finally, when oil is produced, levies and taxes are collected according to the fiscal regime that rules the process. To understand the legislative process in analysis, the timing is relevant, because depending on the landmark employed, the compulsory use of the resources for education will start earlier or later.

The Bill 5,500 proposed the spending of oil revenues in education, anchored in the idea that increasing expenditures in this policy would improve its outcomes. This is a federal centralization, as resource spending becomes determined by the center. Nonetheless, as seen, resources originated in oil exploration are plural and fragmented, multiplying the possibilities for negotiation in order to benefit specific interests. Therefore, the non-monolithic nature of the resources allows for a more nuanced result, rather than an understanding of the outcome as a political gain of the Union. In this regard, the way Bill 5,500 evolved signals quite a complex power dispute, in which the center is not the winner. In order to track those influences, this analysis will single out the elements of the bill in order to understand all the implications involved in the decisions, which indicate how territorial institutional layers conflict with the ideas underlying it.

PL 5,500 featured four resource sources that indicate the power resources that influenced the Bill. The first one included revenue originated in royalty payments to the three levels of government (union, states and municipalities) in the fiscal regimes of concession and profit sharing, for contracts in effect after December 2, 2012. The law is also not limited to revenues in the pre-salt area; other areas are subject to this. However, only areas that were conceded after the established date would have resources earmarked. In concrete terms, due to the long interval between contract and commercial production, however encompassing the scope, education will be benefitted with significant resources only until about 2022 to 2027 .

Second, the Bill also proposed that $50 \%$ of the yields on the revenues on the Pre-Salt Social Fund would be destined to education. Savings funds are not uncommon in the management of oil resources, and there are many ways to deal with the revenues. The "bird-in-hand" model, like the Norwegian oil fund, only disposes yields on revenues, which favors the future generations over the present ones. The social fund, approved in Law 12,351/2010, followed this intergenerational approach, being supplied with revenues originated in the royalties and special participations destined only to the union in the fiscal regimes of concession and onerous cession, located only in the pre-salt area. However, royalties earned in the production sharing contracts would not compose the social fund. In sum, the federal government's proposal may be characterized as future-oriented because it does not alleviate the resource needs in the next 15 years.

Third, the Lower House merged bill no. 5,500/2013 with bill 323, proposed in March 2007. The result was the inclusion of health as a resource destination, as $25 \%$ of the resources should be spent in health care. Besides that, members of the Congress were discontent with the delay on the resource flow. Member of the Congress Izalci noted, "It does not matter that we approve the Bill for Education Now if this will only be effective within eight, ten years. The resource should be spent now. This is what we want to vote in this House." 7 They changed the sources of revenues to answer the need to increase resources in the short term.

In the Lower House, the compulsory use of federal and subnational resources became more encompassing, as the changes that representatives made to the Bill allowed earlier appropriation of resources. Royalties and Special Participation earned by

${ }^{7}$ Representative Izalci (PSDB-DF), in a speech on the Ordinary Deliberative Session, June 25th, 2013, p. 25896 
the federal government, states, and municipalities in contracts in the three fiscal regimes - concession, onerous cession and production sharing - in all offshore territories with declaration of commerciality after December 2012 would be compulsorily applied in education and health (Article 2 nd, items I and II).

Member of the Congress André Figueiredo mentioned the financial impact of this difference:

Several contracts were tendered in 2001, in 2003 and in 2005. As an example, of the seven most promising blocks tendered in 2000 and 2001, in the pre-salt region of the Santos Basin, only two fields, Lula and Sapinhoá, have already declared their commerciality. The Bem-te-vi, Parati and Caramba areas should only enter into commercial production after more than 16 years of bidding. The areas bidding for after 2001 are expected to take more time to enter into commercial operation. Therefore, we put all those, even those tendered in 2001, that have not yet decreed their commerciality, [they] can also go to education, even though they have been contracted, but not yet decreed its commerciality. ${ }^{8}$

Fourth, the combination of both bills led to a significant change in the use of the Social Fund resources, as $50 \%$ of the resources, not the yields, would be destined for education (Article $2^{\text {nd }}$, item III). Social Fund resources were also boosted with federal government's resources, as the substitutive indicated that royalties and special participation from the concession regimes located in the Pre-Salt areas for contracts before December 2012 would be destined to the Pre-Salt Social Fund (Article $2^{\text {nd }}$, item III). As well, union resources from unitization would be destined for public education (Art $2^{\text {nd }}$, Item IV). ${ }^{9}$

This proposal travelled to the Senate, where it suffered further changes for differentiated criteria for federal government' and subnational governments' spending. The reference to declaration of commerciality as a landmark for the resources' destination to education and health was kept for union resources, while subnational resources (states and municipalities) would have the contract landmark. This means that subnational resources will take longer as of discretionary use, while the center money will be destined to established ends.

The idea was to avoid judicial challenges, which was the fate that befell the changes in royalties redistribution in March of the same year, once again indicating the impact of timing and sequence, i.e., previous changes influenced political actors' decisions. The Senate wanted to avoid judicialization with the change to the destination of the resources of the oil fields individualization to health and education, and the determination of a minimum percentage of union participation in the contracts of production sharing, something that could be questioned in court. ${ }^{10}$

Another Senate change that increased the compulsory use of federal government's revenue is related to royalties and special participation of the concession fields located in the pre-salt areas. Those resources would be directed to the social fund in total, and $50 \%$ of the fund principal would be destined to education. This is added to the destination of the fund yields to education and health. Finally, the Senate substitutive indicated that the oil resources could be employed in teachers' payments, as it was only allowed to use the money capital investments. ${ }^{11}$

The Senate sent back the new proposal to the House of Representatives, where it was approved. However, speeches by members of Congress indicate that there was a battle between groups that defended a more immediate appropriation of oil resources to education and health, against another group that intended to postpone it. The latter group won the dispute. One of the members of the Lower House mentioned that there was an agreement among party leaders to approve the Senate's bill. ${ }^{12}$

\footnotetext{
${ }^{8}$ Representative André Figueiredo (PT- RS) in a speech on the Ordinary Deliberative Session, June 25th, 2013, p. 26193. Author's free translation into English. ${ }^{9}$ Not as relevant from a federative standpoint, but important to mention, the PLC proposed a minimum share of $60 \%$ in the profit oil for the union in the profit-sharing contracts.

${ }^{10}$ Individualization a term used in the oil sector to describe the process applied when different concessions reach the same field. The individualization of the field determines each participant's share in the total oil reserve, and it has increased government participation as bigger fields pay more levies due to higher productivity.

${ }^{11}$ Senator Randolfe Rodrigues (PSOL-AP) in a speech on the Ordinary Deliberative Session, July 2ndh, 2013, p. 41862.

${ }^{12}$ André Figueiredo (PDT-CE), speech on the Ordinary session in the House of Representatives, July 10th, 2013, p. 29912.
} 


\section{THE LAW 12,858/2013: FINAL CONFIGURATION}

The text of Law no. 12,858 / 2013 refers to articles 214 and 196 of the federal Constitution in order to justify the spending of resources in education and health. Still referring to constitutional duties, the destination to education seeks to comply with the Constitutional Amendment 59 of 2009, which establishes the application of resources in the area as a percentage of GDP. The destination of the royalties for education was based on this perspective, as evidenced by the text of the National Education Plan (Law 13,005 of June 25, 2014), which indicates in its annex the use of oil resources to achieve its target number 20: "to increase public investment in public education in order to reach at least 7\% (seven percent) of the Gross Domestic Product GDP of the Country in the 5th (fifth) year of this Law and, at a minimum, equivalent to $10 \%$ (ten percent) of GDP at the end of the decade" (Law 13,005 of June 25, 2014, Annex, target 20).

In more detailed terms, Law 12,858 determines which portions of the state's participation in the financial resources originated in the exploration of oil and natural gas will be allocated to the areas of education - with emphasis on childcare, elementary, and secondary education - and health. This transfer is justified in the law by the need to meet constitutional demands in the provision of public services and, to that end, the new law modifies the current legislation that goes back to 1989, Law 7,990 of December 28, 1989.

Law 12,858 determines five sources of funds. The first source originates from royalties and special participations allocated to the Union, whose declaration of commerciality on offshore holdings took effect after December $3 \mathrm{rd}, 2012$. All these revenues should be earmarked for education and health. The second source concerns the royalties and special participations obtained by states, municipalities, and the federal district. This allocation concerns only contracts signed after December 3rd, 2012, which implies a decrease in the resources to be received in the short term in relation to the definition valid for the resources obtained by the union. The third source establishes that $50 \%$ of the resources received by the Pre-Salt Social Fund should be destined for education and health. The fourth source of union resources refers to the ones originating in the agreements for the individualization of production. The fifth originates in the union's share of royalties and special participation in pre-salt fields with exploitation governed by concession contracts and contemplates holdings that have a commercial declaration before December 3, 2012.

Previously, the application of these resources was discretionary and determined by the aforementioned Law 7,990/89. The only condition for using the funds under the previous rule was not to apply them to pay public and permanent debts (Law 12,858). Therefore, resources that were previously spent with a high degree of autonomy are now nationally determined, reducing the decision-making discretion of governments in their use.

\section{CONCLUSIONS}

Our analysis points to the importance of the protests that happened in June 2013, as an external factor, that triggered changes, while influencing consensus-building on the importance of improving health and education. As well, this affected the popularity of incumbent governments and created an inflection point in Brazilian governability pattern. In specific, it shook the president's capacity to impose her preferences over parliament, which created the conditions for her impeachment. The protests created a critical juncture, based on which a new path started. In this regard and aligned with Institutional Theory, demonstrations did not determine the approval of the new legislation but created a path-break that allowed for a new pattern to start.

Its outcome may indicate the return to a governability pattern that seemed to be buried with the economic stabilization plan in 1994. Governability derived from the institutional configuration that attributed powers to the president and party leaders; however, the prevailing configuration since 2013 may be pointing to the importance of other aspects as fundamental to determine Brazil's governability.

Moreover, we argue that timing and sequence play an important role in unfolding new events. The judicialization of the oil rents in federal distribution impacted parliamentarians' decision over some aspects of the compulsory investment of oil windfalls into education and health. Specifically, in March 2013, the federal legislative's decision over more equitable regional distribution of oil rents moved from the parliament to the Supreme Court, giving way to a different appreciation dynamic in which the politicians were no longer in the drivers' seat. 
As the debates in the parliament show, the compulsory investment of oil resources in specific policy areas is also a result of the protests that took place in Brazil in June 2013. In the other hand, the conflict for oil rents, that preceded the issue over discretion, was among producing and non-producing regions. In that regard, it did not primarily involve a conflict between federal and subnational governments, as the scholarly literature on federalism highlights. Protests were important disseminating ideas, but do not fully explain that change, as it was a result of a combination of an institutional framework that gives a prominent role to the federal executive and legislative, and timing and sequencing that had implications on political actors' decisions.

Moreover, the policy result highlights the limits of a dichotomic approaches to federalism, as a close scrutiny in the process shows that the process in analysis can't be understood in the basis of a single centralization-decentralization axis. In this regard, contingency in terms of the substantive policy sector needs to be leveraged to understand the specificities of the issue. In our case, this means understanding how oil contract landmarks impact the decision taken on federal and state governments on the use of the hydrocarbon windfalls.

Further research is needed to understand how a president's loss of popularity affects the ability to impose preferences over parliament. Additionally, as time evolves, the effect of Law 12,858 increases and more resources have to be directed to those fundamental social policies. Monitoring this process may be interesting to have a better grasp over the way the political system reacts to the impacts of this positive resource shock. As well, the natural resources literature point out the dangers that this type of wealth pose to polities, testing the resilience of the institutional structure over interest groups. 


\section{REFERENCES}

ARMIJO, L. E.; FAUCHER, P.; DEMBINSKA, M. Compared to what? Assessing Brazil's political institutions. Comparative Political Studies, v. 39, n. 6, p. 759-786, 2006.

ARRETCHE, M. Democracia, federalismo e centralização no Brasil. Rio de Janeiro: Editora Fiocruz/Editora FGV, 2012.

ARRETCHE, M. Quem taxa e quem gasta: a barganha federativa na federação brasileira. Revista de Sociologia e Política, Curitiba, v. 24, p. 69-85, 2005.

ARRETCHE, M. Financiamento federal e gestão local de políticas sociais: O difícil equilíbrio entre regulação, responsabilidade e autonomia. Ciência \& Saúde Coletiva, v. 8, n. 2, p. 331-345, 2003.

BALKYS, H.; BROWN, D. Policy coordination in federal systems: comparing intergovernmental processes and outcomes in Canada and the United States. Publius, v. 40, n. 3, p. 484-507, 2010.

BANTING, K. G. Canada: nation-building in a federal welfare state. In: OBINGER, H.; LEIBFRIED, S.; CASTLES, F. G. (Eds.). Federalism and the welfare state: New world and European experiences. New York: Cambridge University, 2005. p. 89-137.

BANTING, K. G. Social citizenship and federalism: is a federal welfare state a contradiction in terms? In: GREER, S. L. (Ed.). Territory, democracy and justice: Regionalism and federalism in Western Democracies. New York: Palgrave MacMillan, 2006. p. 44-66.

BÉLAND, D.; LECOURS, A. Federalism, nationalist politics, and social policy: How ideas and institutions shape federal dynamics. In: BENZ, A.; BROSCHEK, J. (Eds.). Federal dynamics: Continuity, change, and the varieties of federalism. Oxford: Oxford University Press, 2013. p. 209-228.

BÉLAND, D. et al. Fiscal Federalism and Equalization Policy in Canada. Toronto: University of Toronto Press, 2017.

BENZ, A.; BROSCHEK, J. Federal dynamics: Introduction. In: BENZ, A.; BROSCHEK, J. (Eds.). Federal dynamics: Continuity, change, and the varieties of federalism. Oxford: Oxford University Press, 2013. p. 1-26.

BICHIR, R.; SIMONI JUNIOR, S.; PEREIRA, G. Sistemas Nacionais de Políticas Públicas e seus efeitos na implementação: O caso do Sistema único de Assistência Social (Suas). Revista Brasileira de Ciências Sociais, v. 35, n. 102, p. 1-23, 2020.

BRASIL. Emenda Constitucional no 29, de 13 de setembro de 2000. Altera os arts. 34, 35, 156, 160, 167 e 198 da Constituição Federal e acrescenta artigo ao Ato das Disposições Constitucionais Transitórias, para assegurar os recursos mínimos para o financiamento das ações e serviços públicos de saúde. Brasília, DF: Congresso Nacional, 2000.

BRASIL. Lei no 9.394, de 20 de dezembro de 1996. Estabelece as diretrizes e bases da educação nacional. Brasília, DF: Congresso Nacional, 1996.

BRASIL. Lei no 11.494, de 20 de junho de 2007. Regulamenta o Fundo de Manutenção e Desenvolvimento da Educação Básica e de Valorização dos Profissionais da Educação - FUNDEB, de que trata o art. 60 do Ato das Disposições Constitucionais Transitórias; altera a Lei n o 10.195, de 14 de fevereiro de 2001; revoga dispositivos das Leis n os 9.424, de 24 de dezembro de 1996, 10.880, de 9 de junho de 2004, e 10.845, de 5 de março de 2004; e dá outras providências. Brasília, DF: Congresso Nacional, 2006.

BRASIL. Portaria no 2.203, de 5 de novembro de 1996. Brasília, DF: Ministério da Saúde, 1996.

BROSCHEK, J.; PETERSOHN, B.; TOUBEAU, S. Territorial Politics and Institutional Change: A Comparative-Historical Analysis. Publius, v. 48, n. 1 , p. $1-25,2018$.

BURGUESS, M.; GRESS, F. Symmetry and asymmetry revisited. In: AGRANOFF, A. (Ed.). Accommodating Diversity: Asymmetry in federal states. Baden-Baden: Homos Verlagsgesehschaft BadenBaden, 1999. p. 43-56.

DARDANELLI, P. et al. Dynamic De/Centralisation in Federations: Comparative Conclusions. In: WORLD CONGRESS INTERNATIONAL POLITICAL SCIENCE ASSOCIATION, 24., 2016, Poland. Proceedings... Poland: IPSA, 2016.

DATAFOLHA. Avaliação da presidente Dilma Rousseff. 2013. Available at: <http://media.folha.uol.com.br/datafolha/2013/07/01/avaliacaodilma.pdf>. Accessed on: Oct. 05, 2020.

DIAS, G.; RENAULT, A. A concentração de recursos na União e as perdas das regiões produtoras. In: GIAMBIAGI, F.; LUCAS, L. P. V. (Eds.). Petróleo: Reforma e Contrarreforma do setor petrolífero. Rio de Janeiro: Elsevier Editora, 2013. p. 153-178

FIGUEIREDO, A.; LIMONGI, F. Instituições Políticas e Governabilidade: Desempenho do Governo e Apoio Legislativo na Democracia Brasileira. In: MELO, C. R.; SAÉZ, M. A. (Eds.). A Democracia Brasileira: Balanço e Perspectivas para o Século 21. Belo Horizonte: Editora UFMG, 2007.

FELIPE, E. S. Mudanças Institucionais e Estratégias Empresariais: a trajetória e o crescimento da Petrobrás a partir da sua atuação no novo ambiente competitivo (1997-2010). 2010. Doctoral Dissertation (Doctor Degree in Economy) - Universidade Federal do Rio de Janeiro, Rio de Janeiro, 2010.

FENWICK, T. B. Avoiding Governors: The Success of Bolsa Família. Latin American Research Review, v. 44, n. 1, p. 102-131, 2009.

FERRARI, D. A. Descentralização Fiscal e Repartição da Receita Pública: o FPE na Constituinte de 1988. 2013. Master Thesis (Master Degree in Political Science) - Universidade de São Paulo, São Paulo, 2013.

GOBETTI, S. W.; SERRA, R. V. Novo Marco Regulatório do Petróleo: desafios na transição do regime de concessão para o regime de partilha. In: PRÊMIO FINANÇAS PÚBLICAS DO TESOURO NACIONAL, 16., 2011. Anais... Brasília, DF: ESAF, 2011.

GREER, S. L. The politics of divergent policy. In GREER, S.L. (Ed.). Territory, democracy and justice: Regionalism and federalism in Western Democracies. New York: Palgrave MacMillan, 2006. p. 157-174.

HUMPREYS, M.; SACHS, J. D.; STIGLITZ, J. E. What is the Problem with Natural Resouce Wealth? In: HUMPREYS, M.; SACHS, J. D.; STIGLITZ, J. E (Eds.). Escaping the Resource Curse. New York: Columbia University Press, 2007. p. 1-20.

LECOURS, A.; BÉLAND, D. The Institutional politics of territorial redistribution: Federalism and equalization policy in Australia and Canada. Canadian Journal of Political Science, v. 46, n. 1, p. 93-113, 2013. 
OBINGER, H.; LEIBFRIED, S.; CASTLES, F. G. (Eds.). Federalism and the welfare state: New world and European experiences. New York: Cambridge University, 2005.

PALERMO, V. Como se governa o Brasil? O debate sobre instituições políticas e gestão de governo. Dados - Revista de Ciências Sociais, v. 43, n. 3, p. 521-557, 2000.

PALERMO, V. Brazilian Political Institutions: an Inconclusive Debate. Brazilian Political Science Review, v. 10, n. 2, e0003, 2016.

RIKER, W. H. Federalism: Origin, Operation, Significance. Los Angeles: Little Brown, 1964.

PIERSON, P. Politics in time: History, institutions, and social analysis. New Jersey: Princeton University, 2004.

SCHARPF, F. W. The join-decision trap: Lessons from German federalism and European integration. In: KINCAID, J. (Ed.). Federalism. London: SAGE Publications, 2011. p. 333-376.

SEGATTO, C. I.; ABRUCIO, F. L. Os múltiplos papéis dos governos estaduais na política educacional brasileira: os casos do Ceará, Mato Grosso do Sul, São Paulo e Pará. Revista de Administração Pública, v. 52, n. 6, p. 1179-1193, 2018.
SIMEON, R. Federalism and social justice: thinking through the tangle. In: GREER, S. L. (Ed.). Territory, democracy and justice: Regionalism and federalism in Western democracies. New York: Palgrave MacMillan, 2006. p. 18-43.

SINGER, A. Brasil, junho de 2013: classes e ideologias cruzadas. Novos Estudos CEBRAP, v. 97, p. 23-40, 2013.

STEPAN, A. Para uma nova análise comparativa do federalismo e da democracia: Federações que restringem ou ampliam o poder do demos. Dados, v. 42, n. 2, p. 197-251, 1999.

TROJBICZ, B. Federalism and Governability in Brazil: Oil Royalties in Dispute. Bulletin of Latin American Research, v. 38, n. 5, p. $607-$ 623, 2019.

TROJBICZ, B. Política pública de petróleo no Brasil: da liberalização ao Pré-Sal. Rio de Janeiro: Elsevier, 2016.

WATTS, R. L. Origins of cooperative and competitive federalism. In: GREER, S. L. (Ed.). Territory, democracy and justice: Regionalism and federalism in Western democracies. New York: Palgrave MacMillan, 2006. p. 201-223.

Beni Trojbicz

ORCID: https://orcid.org/ 0000-0002-0537-8147

Ph.D. in Public Administration and Government; Adjunct Professor at the Interdisciplinary Faculty in Humanities at Federal University of Vales do Jequitinhonha and Mucuri (UFVJM), Minas Gerais - MG, Brazil. E-mail: btrojbicz@gmail.com

Catarina lanni Segatto

ORCID: https://orcid.org/ 0000-0002-5094-8225

Ph.D. in Public Administration and Government; Visiting Professor at Federal University of ABC (UFABC), São Paulo - SP, Brazil.

E-mail: catarina.segatto@gmail.com 


\section{ANNEX}

\section{Interviews}

Abraham Lincoln Ferreira Cardoso. Advisor on Mines and Energy to the Brazilian Democratic Movement Party leadership in the Lower House of Congress. Brasília, DF, July 07, 2014.

Alceu Moreira. Federal Congressman. Porto Alegre, Oct. 20, 2014.

Carlos Zarattini. Federal Congressman. Sao Paulo, Nov. 14, 2014.

Eduardo Stranz. Advisor to the Presidency of the National Confederation of Municipalities. Porto Alegre, Jan. 20, 2015.

Humberto Souto. Former Federal Congressman. Belo Horizonte, Feb. 11, 2015.

Ibsen Pinheiro. Former Federal Congressman. Porto Alegre, June 03, 2014.

Interviewee No. 1. Lower House of Congress Legislative Advisor on Mines and Energy. Brasília, DF, May 14, 2014.

Interviewee No. 2. Lower House of Congress Legislative Advisor on Mines and Energy. Brasília, DF, May 06, 2014.

Interviewee No. 3. Federal Senate Legislative Advisor. Brasília, DF, Apr. 29, 2014.

Jerônimo Cabral Guedes. Advisor on Mines and Energy to the Workers' Party leadership in the Lower House of Congress. Brasília, DF, Feb. 10, 2015.

Leonardo Carneiro Monteiro Picciani. Federal Congressman. Brasília, DF, Dec. 16, 2014.

Marcos Antonio Félix Figueiredo. Advisor on Mines and Energy to the Brazilian Social-Democratic Party leadership in the Lower House of Congress. Brasília, DF, Aug. 14, 2014.

Paulo Teixeira. Federal Congressman. Brasília, DF, Jan. 27, 2015. 